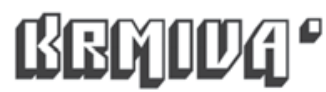

\section{ORGANIC LIVESTOCK IN THE REPUBLIC OF CROATIA AND EUROPE}

\author{
EKOLOŠKO STOČARSTVO U REPUBLICI HRVATSKOJ I EUROPI
}

\author{
Z. Antunović, Đ. Senčić, J. Novoselec, Danijela Samac, Željka Klir \\ Review scientific paper - Pregledni znanstveni članak \\ Received - Primljeno: 14. July - srpanj 2020
}

\begin{abstract}
SUMMARY
The aim of the present study was to analyze the situation in organic livestock farming in Croatia and Europe. In the European countries in the year 2017, around 4.5 million cattle, 5.2 million sheep, 1 million pigs and 50 million poultry were registered in organic farming. The highest share of organically registered domestic animals compared to the total population in Europe and the European Union-28 was in cattle (3.5\% and 5.2\%) and sheep (3.4\% and 5.0\%), and the lowest in pigs $(0.6 \%$ and $0.7 \%)$. In Croatia the highest share is in sheep $(8.57 \%)$ and the lowest in poultry $(0.02 \%)$ number. The largest increase in recent ten years in the EU has been in the number of poultry (by 103\%) and the smallest in the number of pigs (by $47.6 \%$ ), while the increase was the number of cattle and sheep was around $76 \%$ and $74 \%$, respectively. In Croatia organic sheep production increased the most (by $65.0 \%$ ), while the number of cattle and poultry increased by 62 and $64 \%$, and the smallest increase is in the number of pigs (by 24\%). The majority of organic meat of all species of domestic animals is produced in France and in United Kingdom, while organic milk is produced mostly in Germany and France. During the year 2018, most organic beef was produced in the UK and France, organic pork in France and Finland, organic sheep meat in Spain and the UK, organic goat meat in Spain, while most of organic poultry was produced in France and in the UK. A significant increase in the number of livestock in organic farming in Europe and in Croatia indicates an increasing interest in organic livestock farming, not only increase of farmers and processors but also increase of consumers of organic products in European countries.
\end{abstract}

Keywords: organic livestock farming, organic animal products, Croatia, Europe, European Union

\section{INTRODUCTION}

Organic farming can be defined as an approach to agriculture in which the aim is to create integrated, humane, environmentally and economically sustainable agricultural production systems (Blair, 2011). Organic agriculture is the fastest growing branch of agricultural production in the world.
According to Eurostat, 14.6 million ha were under organic farming in European countries at the end of 2017 and 12.8 million ha in the EU-28, which is $2.9 \%$ in Europe and EU-28 7.2\% of total agricultural area (FiBL, 2020). In the world, only Australia has a higher share of organic agricultural land in total agricultural area (8.5\%). The countries with the largest organic agricultural land in Europe are Spain

Prof. dr. sc. Zvonko Antunović, e-mail: zantunovic@fazos.hr, izv. prof. dr. sc. Josip Novoselec, prof. dr. sc. Đuro Senčić, doc. dr. sc. Danijela Samac, dr. sc. Željka Klir, Fakultet agrobiotehničkih znanosti Osijek, Sveučilište J. J. Strossmayera u Osijeku, V. Preloga 1, 31000 Osijek, Croatia. 
(2.1 million ha), Italy (1.9 million ha) and France (1.7 million ha). Comparing the share of organic agricultural land with total agricultural land, the highest percentage shares are in Liechtenstein (38\%), Austria (24\%) and Estonia (20.5\%). According to the data of the Ministry of Agriculture (2019), the share of agricultural organic areas in the total agricultural area in the Republic of Croatia is $6.94 \%$. Antunovic et al. (2020) reported that in the recent five years there has been a significant increase in agricultural land under organic agriculture (by 51.48\%). The aim of organic livestock production is to obtain high-quality food for human consumption, but also to ensure animal welfare and environmental protection (Senčić et al., 2011). Organic livestock production encourages the use of natural resources of a particular farming area in terms of the selection of local genotypes and forages, as well as open barns and canopies, in order to better adaptation of animals to environmental conditions (Antunović, 2011). The development of organic agriculture, and in particular organic livestock farming, has also been driven by changes in the understanding the importance of animal health and welfare as well as abandonment of the anthropocentrism concept. Likewise, the occurrence of various diseases (foot-and-mouth disease, mad cow disease, bird flu, scabies...) caused increased interest in organic livestock farming (Sosnowska-Czajka et al., 2014). Appropriate legislation in the EU has existed since 1991, updated and upgraded in 1999 and 2007, regulating organic africultural production in a good way. The increase in the number of organic producers and processors of organic products in Europe has been significant over the last 10 years. In Europe and in the EU-28 countries, the number of organic producers has increased by almost $79 \%$ and $55 \%$, and the number of organic processors by almost $110 \%$ and $106 \%$ (FiBL, 2020). The largest number of organic producers in Europe has Turkey (more than 75,000) and in the EU-28 Italy (almost 67,000). The largest number of organic processors in Europe is in Italy $(18,092)$. According to the Ministry of Agriculture, in the recent five years the number of persons in organic production has increased by $114 \%$ and the number of processors of organic animal products by $52.28 \%$ (Antunović et al., 2020).
The aim of this research was to analyze the situation in organic livestock in the Republic of Croatia and in Europe.

\section{The state of organic livestock in Europe}

Although statistics are often deficient and sometimes are assesments, they can nevertheless serve as an estimate of a particular manufacturing sector. Analyzing the available statistical databases (EUROSTAT, FiBL, Croatian Bureau of Statistics, MP $\mathrm{RH})$, the situation on organic livestock farming in the Republic of Croatia and Europe will be presented. During 2017, around 4.5 million cattle, 5.2 million sheep, around 1 million pigs and 50 million poultry were registered in European countries for organic livestock farming (Table 1). Comparing the number of registered domestic animals in organic farming with their total numbers in Europe and the EU-28 shows that the highest share in Europe and EU-28 belongs to cattle (3.5\% and 5.2\%) and sheep (3.4\% and $5.0 \%)$ and the lowest to pigs $(0.6 \%$ and $0.7 \%)$. The highest share in the Republic of Croatia is in sheep $(8.57 \%)$ and the lowest in poultry farming $(0.02 \%)$. The highest increase in the recent ten years in the EU (2008-2017) was in the number of poultry (103\%) and the least in the number of pigs (47.6\%), while the increase in the number of cattle and sheep was around $76 \%$ and $74 \%$, respectively. In the Republic of Croatia the number of sheep increased the most (by around $65.0 \%$ ), the number of cattle and poultry increased by 62 and $64 \%$, while the lowest increase was in the number of pigs (by about 24\%). The reasons for this may be due to, among other things, different composition of diets, because the ruminant diet is based on forage feedstuffs whose production is cheaper than non-ruminant diets, where the bulk of the rations are made from concentrates. The production of concentrates is significantly more demanding and more expensive compared to the cost of forage. Furthermore, competition in the food chain between humans and animals, like non-ruminants, is more pronounced.

Table 2 shows the number of organically farmed livestock in European countries and their total number in Europe, EU-28 and the percentage of EU-28 in the total number of livestock registered in organic farming in Europe. 
Table 1 Total number of livestock in Europe, EU-28 and the Republic of Croatia in the year 2017, and percentage of livestock number in organic farming compared with the total number of livestock and its increase in recent 10 years in Europe and recent 5 years in Croatia (FiBL, 2020; EUROSTAT, 2020; Croatian Bureau of Statistics, 2020, MP RH)

Tablica 1. Ukupan broj stoke u Europi, EU-28 i Republici Hrvatskoj u 2017. godini te postotni udio broja stoke u ekološkom uzgoju u ukupnom broju stoke i povećanje broja u zadnjih 10 godina u Europi te zadnjih 5 godina u RH (FiBL, 2020.; EUROSTAT, 2020.; Državni zavod za statistiku RH, 2020., MP RH)

\begin{tabular}{|c|c|c|c|c|c|c|c|c|}
\hline \multirow[b]{2}{*}{$\begin{array}{c}\text { Livestock } \\
\text { species } \\
\text { - Vrsta } \\
\text { životinja }\end{array}$} & \multicolumn{3}{|c|}{ Europe } & \multicolumn{2}{|c|}{ EU-28 } & \multicolumn{3}{|c|}{ Republic of Croatia } \\
\hline & $\begin{array}{l}\text { Animals } \\
\text { (head) } \\
\text { - Životinje } \\
\text { (kom.) }\end{array}$ & $\begin{array}{c}\text { Organic } \\
\text { share (\%) } \\
\text { - Ekološki } \\
\text { udio (\%) } \\
\end{array}$ & $\begin{array}{c}\text { Change, \% } \\
\text { (2008-2017) } \\
\text { - Promjene, \% } \\
(2008 .-2017 .)\end{array}$ & $\begin{array}{l}\text { Animals } \\
\text { (head) } \\
\text { - Životinje } \\
\text { (kom.) }\end{array}$ & $\begin{array}{c}\text { Organic } \\
\text { share (\%) } \\
\text { - Ekološki } \\
\text { udio (\%) }\end{array}$ & $\begin{array}{l}\text { Animals } \\
\text { (head) } \\
\text { - Životinje } \\
\text { (kom.) }\end{array}$ & $\begin{array}{c}\text { Organic } \\
\text { share (\%) } \\
\text { - Ekološki } \\
\text { udio (\%) }\end{array}$ & $\begin{array}{c}\text { Change, \% } \\
\text { (2013-2017) } \\
\text { - Promjene, \% } \\
(2008 .-2017 .)\end{array}$ \\
\hline Bovine & 4398530 & 3.5 & 75.8 & 4159911 & 5.2 & 451000 & 3.82 & 62.03 \\
\hline Sheep & 5187715 & 3.4 & 73.6 & 4941613 & 5.0 & 637000 & 8.57 & 64.45 \\
\hline Pig & 998828 & 0.6 & 47.6 & 961212 & 0.7 & 1121000 & 0.13 & 23.57 \\
\hline Poultry & 50145276 & 2.0 & 103.0 & 47384977 & 3.3 & 10399000 & 0.02 & 63.60 \\
\hline
\end{tabular}

Table 2 Number of livestock in organic farming in European countries and its total number in EU-28 during 2018 (Eurostat, 2019)

Tablica 2. Broj ekološki uzgajanih domaćih životinja u Europi po zemljama i ukupno za EU-28 u 2018. godini (Eurostat, 2019.)

\begin{tabular}{||l|c|c|c|c|c|c||}
\hline \hline Country - Zemlja & Cattle - Goveda & Sheep - Ovce & Goats - Koze & Pigs - Svinje & Poultry - Perad & Horses - Konji \\
\hline Belgium & 106049 & 24670 & 7824 & 17399 & - & - \\
\hline Bulgaria & 9314 & 21072 & 8039 & 24 & 2176 & 232 \\
\hline Czech Republic & 262061 & 94089 & 8857 & 2867 & 49675 & 9399 \\
\hline Denmark & 220754 & 11292 & 2158 & 488886 & 3506802 & 158 \\
\hline Germany & 771320 & 193023 & - & 185401 & - & - \\
\hline Estonia & 41499 & 32901 & 1413 & 458 & 36212 & 1711 \\
\hline Ireland & 61819 & 83302 & 144 & 642 & 161816 & - \\
\hline Greece & 138015 & 1299677 & 494031 & 4746 & 252280 & - \\
\hline Spain & 212066 & 622958 & 76506 & 20196 & 1030745 & 6573 \\
\hline France & 751382 & 1132809 & 109938 & 317925 & 20181495 & 4233 \\
\hline Croatia & 19613 & 62315 & 4199 & 1887 & 1870 & 2088 \\
\hline Italy & 375414 & 680369 & 110055 & 59623 & 3482435 & - \\
\hline Cyprus & 469 & 879 & 4155 & - & 24330 & - \\
\hline Latvia & 96423 & 39407 & 2707 & 1845 & 37417 & 1142 \\
\hline Lithuania & 57884 & 24158 & 1060 & 142 & 16719 & 412 \\
\hline Luxembourg & 4956 & 539 & 333 & 895 & 32528 & 163 \\
\hline Hungary & 18964 & 5538 & 572 & 4459 & 83538 & - \\
\hline
\end{tabular}


Z. ANTUNOVIĆ AT AL.: ORGANIC LIVESTOCK IN THE REPUBLIC OF CROATIA AND EUROPE - EKOLOŠKO STOČARSTVO U REPUBLICI HRVATSKOJ I EUROPI

\begin{tabular}{|l|c|c|c|c|c|c||}
\hline Netherlands & 71715 & 12815 & 50944 & 93210 & - & - \\
\hline Austria & 421953 & 123495 & 51099 & 74594 & 2594068 & 17752 \\
\hline Poland & 26953 & 16243 & 3145 & 3221 & 349697 & 474 \\
\hline Portugal & 93191 & 96620 & 5222 & 2896 & 57548 & 87 \\
\hline Romania & 16890 & 32579 & 1360 & 9 & 83859 & - \\
\hline Slovenia & 35751 & 35071 & 6856 & 3203 & 93145 & - \\
\hline Slovakia & 63340 & 84912 & 1419 & 547 & 5340 & 541 \\
\hline Finland & 72080 & 31985 & 2004 & 4857 & 312202 & 8 \\
\hline Sweden & 332294 & 128914 & 1607 & 33579 & 1411540 & - \\
\hline Great Britain & 324202 & 826598 & 717 & 37440 & 3383126 & 974 \\
\hline Iceland & 236 & 1226 & - & - & 12413 & - \\
\hline Norway & 30307 & 46823 & 1691 & 2924 & 592267 & 35 \\
\hline Switzerland & 200450 & 84765 & 22317 & 38169 & 1053871 & 10577 \\
\hline Northern \\
Macedonia & 6390 & 101317 & 6901 & - & - & - \\
\hline Serbia & 3594 & 5138 & 1486 & 284 & 6735 & 114 \\
\hline Turkey & 5113 & 10457 & 10685 & - & 1242170 & - \\
\hline Europe & 4851834 & 5967974 & 999444 & 1402328 & 40098019 & 56673 \\
\hline EU (28) & 4605744 & 5718230 & 956364 & 1360951 & 37190563 & 45947 \\
\hline \% EU in Europe & 95.00 & 96.00 & 96.00 & 97.00 & 93.00 & 81.07 \\
\hline
\end{tabular}

It is evident that in the year 2018 the largest number of cattle registered in organic farming was in Germany, France and Austria. The largest number of organic sheep was in Greece, France and United Kingdom, and the largest number of organic goats was raised in Greece, Italy and France. The largest number of pigs registered in organic farming was in Denmark, France and Germany, poultry in France, Denmark and Italy, while the largest number of horses was in Austria, Switzerland and the Czech Republic. An analysis on the share of organic livestock in the EU-28 and a comparison with the total number of organically registered livestock in Europe revealed a similar percentage for most livestock, with a lower proportion for horses (81.07\%). The above indicated the importance of the EU countries in the overall European population of livestock registered in organic farming. The presence of ruminants in organic farming in Spain, Germany and in the United Kingdom is significant, which is also associated with the largest registered organic pastures in these countries in Europe.
The analysis of quantities of the most represented organic animal products in Europe, by country and total quantity in EU-28 during 2018, shows that organic meat of all livestock species is produced in France and the UK, while organic milk is produced mostly in Germany and France. During 2018, organic beef was mostly produced in the UK and France, while organic pork was mostly produced in France and Finland. Table 3 presents that most of organic sheep meat in the year 2018 was produced in Spain and the United Kingdom, organic goat meat in Spain, and organic poultry meat in France and in the United Kingdom.

The significant increase in the number of livestock in organic farming in Europe and in the Republic of Croatia indicates an increasing interest in organic livestock farming not only by the farmers and processors, but also by consumers of organic products. 
Z. ANTUNOVIĆ AT AL.: ORGANIC LIVESTOCK IN THE REPUBLIC OF CROATIA AND EUROPE - EKOLOŠKO STOČARSTVO U REPUBLICI HRVATSKOJ I EUROPI

Table 3 Quantity of animal products in Europe, by countries and total quantity in EU-28 during year 2018 (Eurostat, 2019)

Tablica 3. Količina ekoloških animalnih proizvoda u Europi, po zemljama i ukupno za EU-28 u 2018. godini (Eurostat, 2019.)

\begin{tabular}{|c|c|c|c|c|c|c|c|}
\hline \multirow{2}{*}{$\begin{array}{l}\text { Country - } \\
\text { Zemlja }\end{array}$} & \multicolumn{6}{|c|}{ Meat, t - Meso, t } & \multirow{2}{*}{$\begin{array}{l}\text { Milk, t - } \\
\text { Mlijeko, t }\end{array}$} \\
\hline & $\begin{array}{l}\text { Total - } \\
\text { Ukupno }\end{array}$ & $\begin{array}{c}\text { Beef - } \\
\text { Goveđe meso }\end{array}$ & $\begin{array}{c}\text { Pork - } \\
\text { Svinjsko meso }\end{array}$ & $\begin{array}{c}\text { Sheep - } \\
\text { Ovčje meso }\end{array}$ & $\begin{array}{c}\text { Goat - } \\
\text { Kozje meso }\end{array}$ & $\begin{array}{l}\text { Chicken - } \\
\text { Meso peradi }\end{array}$ & \\
\hline Bulgaria & 969 & 866 & - & 63 & 40 & - & 5280 \\
\hline Czech Rep. & 13106 & 12217 & 157 & 545 & 19 & 167 & 33433 \\
\hline Denmark & 6643 & 6643 & - & - & - & - & 689600 \\
\hline Germany & - & - & - & - & - & - & 1117821 \\
\hline Estonia & 3404 & 3071 & 38 & 255 & 4 & 29 & 7386 \\
\hline Ireland & 2361 & - & - & - & - & - & 17791 \\
\hline Greece & 839 & - & - & - & - & - & 75722 \\
\hline Spain & 35803 & 23004 & 1939 & 8569 & 491 & 1289 & 42006 \\
\hline France & 68948 & 29388 & 14837 & 1684 & - & 23039 & 909336 \\
\hline Croatia & 2311 & 1456 & 141 & 571 & 17 & 2 & 3094 \\
\hline Cyprus & 28 & - & - & - & - & - & 3706 \\
\hline Latvia & 1629 & - & - & - & - & - & 94327 \\
\hline Lithuania & 803 & - & - & - & - & - & 68133 \\
\hline Luxembourg & 187 & 116 & 70 & 1 & - & - & 3772 \\
\hline Hungary & 1110 & - & - & - & - & - & 4721 \\
\hline Austria & - & - & - & - & - & - & 635751 \\
\hline Poland & - & - & - & - & - & - & 26773 \\
\hline Romania & 8 & - & - & - & - & - & 28062 \\
\hline Slovenia & 410 & - & - & - & - & - & 7187 \\
\hline Slovakia & 66 & - & 740 & - & - & - & 25998 \\
\hline Finland & 3710 & 2610 & 5540 & 360 & - & - & 71028 \\
\hline Sweden & 29750 & 21806 & 2800 & 1187 & - & 1217 & 464970 \\
\hline Great Brit. & 53800 & 31600 & - & 7600 & - & 11800 & 564000 \\
\hline Iceland & 23 & - & 394 & - & - & - & 402 \\
\hline Norway & 3101 & 1603 & - & 641 & 4 & 459 & 51667 \\
\hline Serbia & 14 & 11 & - & - & - & 3 & 7120 \\
\hline Turkey & 1688 & 362 & - & 50 & 14 & 1261 & 12884 \\
\hline Europe & 230711 & 134753 & 26656 & 21526 & 589 & 39266 & 4971970 \\
\hline EU (28) & 225908 & 132777 & 26656 & 20835 & 571 & 37546 & 4900300 \\
\hline \% EU in Europe & 98.00 & 99.00 & 100.00 & 97.00 & 96.94 & 95.62 & 99.00 \\
\hline
\end{tabular}




\section{LITERATURA}

1. Antunović, Z. (2011): Ekološki uzgoj ovaca i koza. U: Ekološka zootehnika. Urednik Senčić, Đ.. Poljoprivredni fakultet u Osijeku, str. 92-122.

2. Antunović, Z., Senčić, Đ., Klir, Ž., Samac, D., Novoselec, J. (2020): Organic livestock in Republic of Croatia- state and perspectives development. Book of Abstarcts GEA (Geo Eco-Eco Agro) International Conference, 28 May 2020. Montenegro, p. 207.

3. Blair, R. (2011): Nutrition and feeding of organic cattle. CABI International, p. 293.

4. HPA (2019): Godišnje izvješće. Ovčarstvo, kozarstvo i male životinje. MP RH, Zagreb, str. 123.

5. Senčić, Đ., Antunović, Z., Mijić, P., Baban, M., Puškadija, Z. (2011): Ekološka zootehnika. Poljoprivredni fakultet u Osijeku, str. 239.
6. Sosnowska-Czajka, E., Skomorucha, I., Muchacka R. (2014): Characteristics of organic livestock farms in Poland in 2009-2011. Ann. Anim. Sci. 15,1, 197210.

7. Research Institute of Organic Agriculture FiBL \& IFOAM (2020): The World of Organic Agriculture - Statistics and Emerging Trends (2019). Willer, H., Lernoud, L. (Eds.). Research Institute of Organic Agriculture FiBL; IFOAM - Organics International http://www.organic-world.net/yearbook/yearbook2019.html

8. http://appsso.eurostat.ec.europa.eu/nui/submitView TableAction.do\# (EUOSTAT)

9. https://www.dzs.hr/

10. https://www.mp.hr/

\section{SAŽETAK}

Cilj je ovoga istraživanja bio analizirati situaciju u ekološkom stočarstvu u Republici Hrvatskoj i Europi. U europskim zemljama 2017. u ekološkim uzgojima, evidentirano je oko 4,5 milijuna goveda, 5,2 milijuna ovaca, oko 1 milijun svinja te oko 50 milijuna peradi. Najveći udio ekološki registriranih domaćih životinja u usporedbi s ukupnom populacijom u Europi i EU-28 je za goveda (3,5\% i 5,2\%) i ovce $(3,4 \%$ i $5,0 \%)$, a najniži za svinje (0,6\% i 0,7\%). Najviši udio u Republici Hrvatskoj je ovaca $(8.57 \%)$, a najniži peradi $(0,02 \%)$. Najveće povećanje u zadnjih deset godina u EU je broja peradi (za 103\%), a najmanje broja svinja (za 47,6\%), dok je povećanje broja goveda i ovaca bilo oko 76\% i 74\%. U Republici Hrvatskoj u ekološkim uzgojima najviše je povećan broj ovaca (za oko 65,0\%), dok je broj goveda i peradi porastao za oko 62 i 64\%, a najmanje je povećan broj svinja (za oko 24\%). Najviše je ekološkog mesa svih domaćih životinja proizvedeno u Francuskoj i Velikoj Britaniji, a ekološkog mlijeka u Njemačkoj i Francuskoj. Tijekom 2018. godine proizvedeno je najviše ekološkog goveđeg mesa u Velikoj Britaniji i Francuskoj, ekološkog svinjskog mesa u Francuskoj i Finskoj, ekološkog ovčjeg mesa u Španjolskoj i Velikoj Britaniji, ekološkog kozjeg mesa u Španjolskoj, a ekološkog mesa peradi u Francuskoj i Velikoj Britaniji. Utvrđeno značajno povećanje broja domaćih životinja u ekološkim uzgojima u Europi i u RH ukazuje na sve veći interes za ekološkim stočarstvom ne samo uzgajivača i prerađivača nego i konzumenata ekoloških proizvoda u europskim zemljama.

Ključne riječi: ekološko stočarstvo, ekološki animalni proizvodi, Hrvatska, Europa, Europska unija 